\title{
COMMENTARY
}

\section{Politically Motivated Prosecutions and Detentions: Grand Chamber judgment in the case of Selahattin Demirtaş v. Turkey (no. 2)}

\author{
Özgür H. Çınar ${ }^{1}$
}

\begin{abstract}
This is a commentary paper by focusing on the European Court of Human Rights Grand Chamber's judgment in the case of Selahattin Demirtas $v$. Turkey (no. 2). It is a controversial judgement which has received substantial international attention. In this case, the Court has been given the opportunity to reiterate its key positions on a highly important aspect of freedom of expression (Article 10), the right to liberty and security (Article 5) and the right to free elections (Article 3 of Protocol No. 1). In addition, the Court has for the first time handed down a judgment finding that Article 18 had been violated in conjunction with Article 5. Finally, this judgement is remarkable because it raises the question of what to do when Contracting Parties do not comply with ECtHR judgments (Article 46).
\end{abstract}

Keywords: European Court of Human Rights; Grand Chamber; Demirtas judgment.

\section{Introduction}

On the 22nd of December 2020, the European Court of Human Rights (ECtHR or 'the Court') delivered its Grand Chamber judgment in Selahattin Demirtaş v Turkey (No. 2) (application no. $14305 / 17){ }^{2}$ It is a controversial judgement which has received substantial international attention. As a result of this controversy, the website of the ECtHR was even subjected to a large-scale cyberattack, which rendered it temporarily inaccessible (Council of Europe, 2020).

In this case, the Court has been given the opportunity to reiterate its key positions on a highly important aspect of freedom of expression (Article 10), the right to liberty and security (Article 5) and the right to free elections (Article 3 of Protocol No. 1). In my opinion, the crucial point of this decision is the Court's focus on the limitations on use of restrictions on rights (Article 18 in conjunction with Article 5). The Court has for the first time handed down a judgment finding that Article 18 had been violated in conjunction with Article 5. Furthermore, the judgment differs from previous ones in that it criticises the current state of democracy in Turkey by reaching the conclusion that the arrest and trial of the applicant had been politically motivated. By ordering the immediate release of the applicant, the Court reminds all Contracting Parties (and specifically Turkey) of their obligation under Article 46 to take execution measures that comply not only with the conclusions, but also the spirit of its

\footnotetext{
${ }^{1}$ Dr Özgür H. Çınar, A lawyer and an associate professor, University of Greenwich, School of Law and Criminology, London, United Kingdom. E-mail: o.h.cinar@gre.ac.uk.

2 Selahattin Demirtaş v. Turkey (No. 2). Application no. 14305/17. 22 December 2020. http://hudoc.echr.coe.int/eng?i=001207173 (last accessed 19.02.2021).
} 
judgments. Finally, the judgment raises the question of the limits of the Council of Europe's (CoE) capacity to ensure Contracting Parties comply with the Court's judgments since Turkish politicians have already stated they will not execute this judgment.

\section{Facts}

The applicant, Mr Demirtaş, (who is still detained in Edirne, Turkey, at the time of writing March 2021- this article) was one of the co-chairs of the Peoples' Democratic Party (HDP), a left-wing pro-Kurdish political party. Between 2007 and 2018, he was a member of the Turkish Grand National Assembly ("the National Assembly") and stood in the 2014 and 2018 presidential elections $(\$ 15,16)$.

Beginning on 2 October 2014, protests against the Daesh attacks on Kobani took place in various cities in Turkey, and non-governmental organisations issued calls for international solidarity with the people of Kobani (\$18). On 6 October, these protests turned violent as different groups clashed and the security forces intervened. Curfews were imposed in some cities as violence escalated $(\$ 23)$. The President of Turkey gave a statement to the press blaming the HDP leaders. The President even stated that they would have to "pay the price" for the acts of terrorism (\$35).

After efforts to form a coalition government following the 7 June 2015 elections failed, another election was held on 1 November 2015 (\$43). At this election the AKP regained its majority in the National Assembly (\$46). The following year, on 20 May 2016, MPs approved a constitutional amendment that opened the way for the parliamentary immunity of MPs to be removed in cases where requests for the lifting of immunity had been made to the National Assembly before the date the amendment was approved $(\$ 56)$. This amendment affected 154 MPs ( $\$ 57)$. Once the constitutional amendment had come into force, the Diyarbakır public prosecutor combined 31 separate criminal investigations regarding Mr Demirtaş into a single case (\$63). Between July and October 2016 public prosecutors summonsed him to give evidence on six occasions. However, Mr Demirtaş did not give evidence to the prosecutors in question (\$64).

On 4 November 2016 twelve HDP members of parliament, including Mr Demirtaş, were arrested by the police (\$66). On the same day the Diyarbakır 2nd Magistrate's Court ordered $\mathrm{Mr}$ Demirtas to be detained prior to a trial for membership of an armed terrorist organisation and incitement to commit an offence $(\$ 70)$. Courts in other cities ordered the pre-trial detention of eight other HDP MPs. On 7 December 2018 Mr Demirtaş began a prison sentence of four years and eight months ( $\$ 291)$.

Between 17 November 2016 and 11 December 2018, Mr Demirtaş made several individual applications to the Turkish Constitutional Court, the highest court in Turkey. On 21 December 2017 the Constitutional Court handed down its first judgment regarding $\mathrm{Mr}$ Demirtaş’s pre-trial detention, stating his application was inadmissible (\$96).

On 9 June 2020 the Constitutional Court issued a further judgment, finding unanimously that a violation of Article $19 \$ 7$ of the Turkish Constitution (corresponding to Article $5 \$ 3$ of the Convention) had occurred due to the period of time Mr Demirtaş had been in pre-trial detention (\$121). The Constitutional Court declared that there had not been relevant or sufficient grounds to extend his detention. Concerning his present pre-trial detention, $\mathrm{Mr}$ 
Demirtass has made another application to the Constitutional Court. This application is still pending before the Court (\$128).

In addition, the applicant petitioned the ECtHR on 20 February 2017. A Chamber judgment was delivered on 20 November 2018. On 19 February 2019 the applicant and the Government each requested that the case be referred to the Grand Chamber. On 18 March 2019 the panel of the Grand Chamber accepted their respective requests.

\section{Judgment of the Grand Chamber}

\section{Article 10}

The Court concluded that Mr Demirtaş's right to freedom of expression enshrined in Article 10 had been violated by the lifting of his parliamentary immunity, his first and continuing pretrial detention, and the prosecution for terrorism-related offences on the basis of political speeches he had made. Furthermore, the interference in his rights had not been prescribed by law as required by Article 10(2). The Court underlined the importance of safeguarding the freedom of expression of those elected to represent the people, particularly that of members of opposition parties. ( $(270,281$ and 282).

\section{Article $5 \$ 1$ and 3}

As regards Article 5, the domestic courts had not presented any specific facts or information that could have led to a suspicion necessitating the detention of the applicant before trial, nor at any time during his detention. Hence, there was no reasonable suspicion that he had committed the offences in question. Consequently, the Court found there had been a violation of Article $5 \int 1$ of the Convention due to the absence of reasonable suspicion that the applicant had committed an offence. As for Article 5 \& 3 of the Convention, the Court stressed that the existence of a reasonable suspicion that an individual had committed an offence was an absolutely necessary condition for continued detention (see Merabishvili v. Georgia, \$222). As no such suspicion existed, the Court concluded that a violation of Article $5 \int 3$ had also taken place $(\$ 340,354)$.

\section{Article 3 of Protocol No. 1}

The Court concluded that the domestic courts had been in contravention of their procedural obligation under Article 3 of Protocol No. 1 because they had not established whether or not Mr Demirtaş had been entitled to parliamentary immunity for the statements on the basis of which the prosecution had been commenced. The Court also found that the domestic courts had not considered the conflicting interests or the fact that Mr Demirtaş was a significant leader of the opposition in the country. Hence, the Court concluded that the detention of the applicant prior to trial was incompatible with his fundamental right under Article 3 of Protocol No. 1 to be elected and take his place in Parliament $(\$ 397,398)$.

\section{Article 18 in conjunction with Article 5}

The Court declared that the grounds submitted by the authorities for the detention of the applicant was intended to mask an ulterior political purpose, a very serious matter for democracy (\$436). It concluded that, beyond reasonable doubt, it had established that the applicant's detention, in particular during two important political campaigns concerning the 
referendum of 16 April 2017 and the presidential election of 24 June 2018, had, in reality, the ulterior purpose of suppressing pluralism and restricting the freedom of political debate, something which is absolutely fundamental in a democratic society ( $(435)$. Therefore, a violation of Article 18 of the Convention in conjunction with Article 5 (\$438) had occurred.

\section{Article 46}

To continue the applicant's pre-trial detention, on the same basis, would be to prolong the violation of his rights, in addition to violating the obligation of the respondent State to comply with the Court's judgment in accordance with Article 46 \$ 1 of the Convention. Consequently, the Court declared that the respondent State must take all necessary measures to ensure the immediate release of the applicant $(\$ 442)$.

\section{Comment}

In this judgment, the Court emphasises that not releasing Demirtaş will perpetuate the violations of his rights. Unlike the Chamber case of November 2018, the Court concluded that the charges and detention of Demirtaş were "not based on a reasonable suspicion" ( $(340)$. The Court also found that the reasons given for Demirtaş's detention were insufficient, thereby strengthening the original judgment handed down by the Court in 2018. Firstly, the Court condemns the lifting of immunity and states that the arrest of Demirtas and the other members of parliament resulted from changes to the constitution. Secondly, the Court points out, after having examined the accusations of "terrorism" made against Demirtaş, that his speeches do not even amount to propaganda for terrorism. Thirdly, it states that the judgment relating to membership of an organisation was unforeseeable and arbitrary (Bulut, 2020).

While these are the main points of the judgment, it is also significant in other respects as follows:

Firstly, the Court concluded that in Turkey arrests and trials take place on political grounds and that at the present time the political conditions in Turkey are not conducive to the implementation of the Convention or the establishing of democracy. This judgment clearly differs from earlier case-law, where the Court seemed reluctant to properly criticise the state of democracy in Turkey. Here, however, it indicates that the continuation of Demirtaş' detention is emblematic of the current undemocratic nature of the Turkish political landscape. It gives as an example the fact that Demirtaş was unable to participate and campaign in two elections. The judgment also shares concerns that the judicial system in Turkey is not independent and impartial. Consequently, the Court found that the applicant is being held in detention for political reasons, being a violation of Article 18 in combination with Article 5, the first time the Court has handed down such a judgment (Şimşek, 2018).

This judgment of a violation of Article 18 also rules out the possibility that Demirtaş could be released and then re-arrested for political reasons. The judgment also encapsulates all the other HDP MPs who were detained on politically motivated charges. Hence, the Court's reliance on Article 18 was a smart decision inasmuch as it ensures that the Demirtaş judgement has a broader effect (Aktan, 2020).

Secondly, what makes this judgment interesting is that the Court reminds contracting states of their obligations contained in Article 46. The reason for this stance of the Court is the attitude of Turkish government officials to Court judgments (BBC, 2020). For instance,

\section{Border Crossing}


following the judgment handed down in 2018, President Recep Tayyip Erdoğan said: "The decisions delivered by the ECHR do not bind us" (Hürriyet Daily News, 2018). In this judgment, the Court is sending a clear message to the politicians in Turkey regarding their obligations arising from the Convention, stressing once again the significance of Article 46. In other words, it is a precise message that the execution measures must not only comply with the conclusions, but also the spirit of the judgement. With this regard, domestic law also matters. In addition to Article 46 of the Convention clearly stating that ECtHR judgments are binding, Article 90(5) of the Turkish Constitution sets out that international conventions are part of Turkish domestic law and that in the event of discrepancy international conventions shall be applied. In other words, this article gives pre-eminence to the Convention ahead of Turkish laws.

Thirdly, this judgement is remarkable because it raises the question of what to do when Contracting Parties do not comply with ECtHR judgments. In spite of Article 46 of the Convention and Article 90(5) of the Turkish Constitution being absolutely clear, the Turkish courts have still not ordered the release of Mr Demirtaş at the time of writing. Turkish politicians have even made statements saying they will not comply with the judgment (European Parliament, 2021). At this juncture the question arises as to what sanctions could be applied in the event of Turkey's non-compliance with this judgment. The Committee of Ministers of the $\mathrm{CoE}$ is responsible for overseeing the implementation of ECtHR judgments by member states. For instance, in the event of another violation of the law in question, the Committee can even demand a change in the law. However, if a contracting state insists on the non-implementation of judgments, the Parliamentary Assembly of the CoE has the power to suspend or terminate the membership of a state. Of course, while the suspension or termination of Turkey's membership of the $\mathrm{CoE}$ is at the moment unlikely, it is not unthinkable that this would become something to consider, depending on the evolution of this case.

Finally, this judgment is also a serious test for the CoE. Given the statements made by Turkish leaders that they would not abide by the judgment, people are curious as to what steps the $\mathrm{CoE}$ will take in order to safeguard the reputation of the Court. In other words, this judgment is important as it has reignited the long-running debate as to whether the Committee of Ministers and the Parliamentary Assembly take judgments of the Court seriously and to what degree they protect the prestige of the Court.

\section{Conclusion}

It is important that Turkey firstly immediately releases Mr Demirtaş and others in his position, rather than persisting with an attitude of not recognising Court judgments, which does not comply with either Article 46 of the Convention or Article 90(5) of its own Constitution. Additionally, in light of this judgment, the member States of the CoE must again understand the importance of establishing independent and impartial judicial mechanisms, taking into consideration the democratic principles. Indeed, judicial bodies must make decisions based on fundamental human rights and freedoms, not on political grounds. Finally, people are interested in what the response of the mechanisms of the CoE will be following declarations by Turkish officials that they will not abide by the judgment. The Convention states that the necessary measures must be taken as soon as possible. If the necessary steps are not taken, judgments of the Court will lose all authority and prestige. 


\section{References}

Aktan, İ. (2020, December 22). Mahsuni Karaman: Çok sürmez, Demirtaş serbest birakılacak. Gazete Duvar. https://www.gazeteduvar.com.tr/mahsuni-karaman-cok-surmez-demirtas-serbest-birakilacak-makale-1508351

BBC. (2020, December 23). Erdogan attacks Europe court's order for Demirtas's release. BBC. https://www.bbc.co.uk/news/world-europe-55424251

Bulut, B. (2020, December 23), Erdoğan'ın AİHM'nin Demirtaş kararına dair açılaması sonrası süreç nasil işleyecek? Evrensel. https://www.evrensel.net/haber/421906/erdoganin-aihmnin-demirtaskararina-dair-aciklamasi-sonrasi-surec-nasil-isleyecek

Council of Europe. (2020, December 2020). Cyberattack on the website of the European Court of Human Rights. https://www.coe.int/en/web/portal/-/cyberattack-on-the-website-of-theeuropean-court-of-human-rights

European Parliament. (2021, January 19). European Parliament resolution on Human rights situation in Turkey, notably the case of Selahattin Demirtas and other prisoners of conscience

(2021/2506(RSP)). https://www.europarl.europa.eu/doceo/document/B-9-2021-0084_EN.html

Hürriyet Daily News. (2018, November 20). Erdoğan rejects European court's 'non-binding' decision over Demirtaş. Hürriyet Daily News. https://www.hurriyetdailynews.com/european-court-urgesturkey-to-free-demirtas-139022

Selabattin Demirtas v. Turkey (No. 2). Application no. 14305/17. 22 December 2020. http:// hudoc.echr.coe.int/eng?i=001-207173

Şimşek, B. (2018, November 21). AİHM Demirtaş kararı: 5 soruda kararın önemi ve olası etkileri. BBC. https://www.bbc.com/turkce/haberler-turkiye-46277190. 